\title{
A letter home: \\ Grundtvig in Cambridge to his wife Lise, June 1831
}

\author{
By S. A. J. Bradley
}

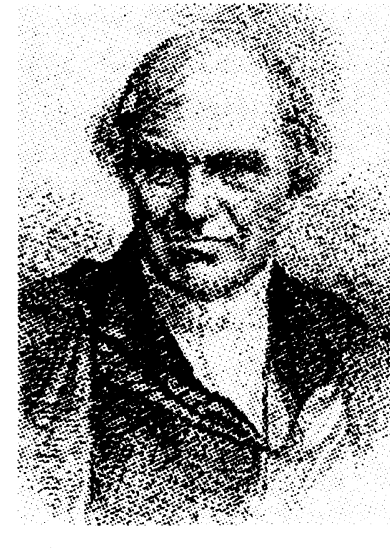

The Revd, Dr. William

Whewell, Master of

Trinity College

Cambridge, Grundtvig's

host in Cambridge (1831)

and his friend of many

years

In 1828 Grundtvig gained the King's support to seek out and study in the libraries of England Anglo-Saxon and later medieval manuscripts which might shed light on the ancient history and culture of Denmark and the North, just as Thorkelin a generation previously had gone to London to retrieve from obscurity the Anglo-Saxon poem Beowulf, with its Danish legendary content.

For many years, the received orthodoxy has been that this antiquarian motivation for the visits of 1829,1830 and 1831 was soon displaced by Grundtvig's dynamic response to his encounter with contemporary England. But the nature of the Anglo-Saxon cultural legacy which Grundtvig had been intermittently but widely exploring since in 1815 he first taught himself the Anglo-Saxon language in order to read Beowulf, and of which Beowulf itself is only a small and in some respects untypical part, has remained seriously under-researched and underestimated within Grundtvig-scholarship. His letters from England, notably those sent to his wife and to Christian Molbech of the Royal Library in Copenhagen, certainly record his fascinated observation of contemporary English society, institutions and values, but they also chart his abiding preoccupation with the manuscript legacy of the earliest Christian culture of the 'nordic' world. A full and detailed assessment of what Grundtvig encountered in these manuscripts - and also in the editions of their contents by earlier scholars (L'Isle, Spelman, Junius, Wheloc, Thwaites, Rawlinson, Hickes, Wanley, Warton, Conybeare) from the seventeenth, eighteenth and nineteenth centuries, such as were available for Grundtvig to read in the Royal Library and the University Library in Copenhagen - would doubtless affect the conventional account of Grundtvig's intellectual and spiritual 
evolution in the years leading up to Nordens Mythologi (1832) and the years beyond.

The following letter was written from Cambridge in the last of the three successive summer-visits, and it well reflects both the sense of mission Grundtvig had towards the manuscripts and the unanticipated stimulation he found in the congenial context of English academic life, to which a letter of commendation from the Danish scientist H. C. Ørsted had introduced him.

The letter is offered here as a specimen from a volume of the England-letters (translated by Helene Felter and S. A. J. Bradley; based in part upon $N$. F. S. Grundtvigs Breve til hans Hustru under Englandsrejserne 1829-1831. Udgivne af deres Børnebørn, Copenhagen 1920), now in preparation as part of the English Translation Project in the Centre for Grundtvig Studies, University of Aarhus.

The Project has been established in order to make primary writings of Grundtvig more accessible to the English-speaking world. Funded initially for a period of three years by grants under the overall administration of Jens Holger Schjørring (Aarhus), work began in October 2001 under the direction of S. A. J. Bradley (on subsidised secondment from the Department of English \& Related Literature, University of York, England) in collaboration with Kim Arne Pedersen (Aarhus) and A. M. Allchin (Bangor). The first volume, expected to be published by the University of Aarhus Press in September 2003, will be an annotated biographical anthology of writings by Grundtvig and memoirs of Grundtvig by his contemporaries. This will be followed by volumes representing Grundtvig's vigorous engagement with the AngloSaxon heroic poem Beowulf, correspondence relating to the Englandvisits of 1829-1831, and key educational writings. Translations of a selection of Grundtvig's sermons and hymns are also in progress. 
Cambridge, 14 June 1831

\section{Dear good Lise!}

I have not yet heard anything from all of you at home, but still I hope that the same Lord who has so evidently made all things well where I am come to, does not appear to have forgotten those who were left behind!

From the heading, you will see that I am already several days into my stay in Cambridge; and I shall certainly remain here at least until the end of the week, since there is enough for me to do here, and I have never had such good days in England as here, where I have lighted upon a small circle of knowledgeable, friendly, Christian-minded priests and professors whom I casually drop in upon when I am not poring over the manuscripts. I had a letter in fact from State-Councillor Ørsted ${ }^{1}$ to a Professor Babbage ${ }^{2}$ who lives in London but belongs here. Him I was so lucky as to meet on Thursday evening, and when he heard that I wanted to leave the next morning, he immediately sat down and wrote letters to important people all of whom I have also found at home, even though the vacation has already started and nearly everybody has fled.

The first person I visited here on Saturday was a Professor of Mathematics, Whewell, ${ }^{3}$ who lives in one of the colleges (Trinity College). As soon as he saw my name and business, he recognised it from my Prospectus, dressed and went around with me to whoever I needed to see - whereupon precisely those books I was seeking were immediately taken out of the library down to the study of the Master of the College, where I can pore over them at leisure.

In the colleges one eats in a great hall at long tables with benches as in farmhouse living-rooms; ${ }^{4}$ and since the fellows can bring whom they will with them to table, I eat now here and now there, wherever those of us who know each other meet. However, it is especially Professor Whewell and a Dr Rose ${ }^{5}$ who is also a fellow at Trinity College but who is married, lives in town and has a benefice in the country - especially these two I associate with; and today I am probably moving into Trinity College because the inn I have ended up in does not please me at all, and Whewell is adamant that I must not move to another one. He is a different mathematician from those we are used to seeing, and there 
prevails such a truly free, lighthearted and serious tone that I feel myself more at home than would have been the case at Copenhagen University.

Trinity College 16 June

Dear Lise! In vain I waited to see some lines from home with the last post; but I will hope that the only reason for this is that you would not write (which after all was considerate) before you saw a letter from London.

You will see I have now properly moved into the college where I live very pleasantly just above Professor Whewell (Hvuel) ${ }^{6}$ who continues to look after me in the kindliest manner. Whatever there was to be found of Anglo-Saxon in the College library he has had brought down to my room which is something invaluable. I saw Dr Rose for the last time yesterday when we ate lunch together with the Professor of Arabic, Lee, ${ }^{7}$ because today Rose leaves for his benefice. His brother however, also a priest ${ }^{8}$ lives next door to here in St John's College, where I am taking lunch today. At the University Library too, everything goes according to my wishes. I had a letter from Professor Babbage to the Librarian ( $\mathrm{Mr}$ Lodge) whom I have been together with almost every day since, and with whom I recently dined in Magdalene College. Where I have not met with any hospitality is rather at Corpus Christi College, where I have mostly worked in the Master's (Dr Lamb's) own study; but that is so much more reason to appreciate that I came there at all, and all the other colleges' goodwill could not have compensated me for a lack of free access to the Saxon books here, ${ }^{9}$ whilst they can easily console me for the other deficiency.

Yesterday after dinner I was with Professor Whewell at the Astronomical Observatory, which lies three quarters of a mile's distance from town, and there we drank tea with the lady of the house (who did not have anything over her shoulders other than black locks, for her white dress was sitting below them), but the astronomer sat like a wizard and stargazed, so him I saw only a privy glimpse of, when it was granted us in deepest silence to peep inside sanctuary. The man is called Airy ${ }^{10}$ (luftig) - and, since it is about things in the air that he is supposed to be wise, the name does not put him to shame; but otherwise it will have to have been a distinguished star he sat and peered at if this sort of thing is not, in my eyes, to be seen as the behaviour of a windbag.

I drank tea at Heaton's ' ${ }^{11}$ (you doubtless recall) the evening before I left London, and his wife was as coquettish this year as last, and among the rest would in no way believe my honest assurance that I would not be able to recognise Mrs Bolton again if I saw her. 
I shall probably remain here the rest of the week and maybe a little into the next and, were it not that the friends will soon take flight each to his own quarter, ${ }^{12}$ I could surely have worked longer.

Now God grant both that you, dear wife, may be a good deal healthier than when I left and that the children and Jane are well so that you can enjoy yourselves in the summer weather which I assume you too have got. Black (the publisher) ${ }^{13}$ had not yet come home from Germany when I left London, so in that respect I do not know whether I am bought or sold, but I trust in our Lord and I hasten to do here what cannot be done at any other time.

Most affectionate greetings to Johan, Svenn, Meta, Jane, ${ }^{14}$ all the siblings and friends, from your husband,

N. F. S. Grundtvig.

Notes

1. Hans Christian Ørsted (1777-1851) was the discoverer (1820) of electromagnetism and (1824) aluminium, and the moving force behind the establishment (1829) of Den polytekniske læreanstalt, the polytechnic college, in Copenhagen - one star in the remarkable galaxy of talent scintillating at that time in Denmark's capital city, and a man with international scholarly connections, here working to Grundtvig's advantage.

2. Charles Babbage (1792 - 1871), Professor of Mathematics in Cambridge, $1828-1839$.

3. William Whewell (1794 - 1866), with whom Grundtvig was to keep up contact for some years, was priest, mathematician, natural scientist, and philosopher; from 1828 to 1832 professor of Mineralogy, from 1838 to 1855 professor of Moral Philosophy; fellow and later Master (1841-66) of Trinity College, and Vice-Chancellor of the University of Cambridge 1842 - 43, 1855 - 56. He had studied German philosophy, particularly the work of Kant which was an influence upon certain areas of his own thinking; and he spoke the language fluently. Though much yet lay ahead before he attained the peak of his career and influence in Cambridge, Whewell already had a reformer's mind (he would subsequently introduce new disciplines linked with science); and he was regarded as a warm and friendly man, exactly as Grundtvig indeed found him to be. Grundtvig subsequently wrote a short poem in English was a token of that gratitude which I will never be competent to express in a foreign tongue " (Poetiske Skrifter, V, 500 - 501). For the engraving of Whewell reproduced here I am grateful to David Alexander of York. 
4. The image »som i Bønder-Stuer « conveys a rather misleading impression of the dining arrangements which still today prevail in the great halls of the Oxford and Cambridge colleges; but Grundtvig no doubt meant to emphasise the striking communality of the college life by drawing an analogy with the traditional common table of the Danish farmer's household and farmhands. It was in part his (perhaps rather idealised) notion of the beneficial communality of teachers and taught within the English universities which led him later to develop his model of the Danish folkhighschool.

5. Hugh James Rose (1795 - 1838) was congenial company for Grundtvig in that he was an opponent of German rationalism in theology. He was one of several High Church Anglicans with whom Grundtvig came into contact.

6. 'Hvuel' is Grundtvig's best shot at presenting Whewell's difficult name phonetically.

7. Samuel Lee (1783 - 1852) was Cambridge's equivalent of Rasmus Rask in Copenhagen; an orientalist who became Professor of Arabic and subsequently of Hebrew in Cambridge, learned in some eighteen languages, who published texts of the Bible in several oriental languages.

8. Henry John Rose (1800 - 1873), noted as the editor of the New General Biographical Dictionary.

9. Grundtvig had good reason for rating access to Corpus Christi College's Anglo-Saxon manuscripts a priority. They form one of the most important collections in England, being essentially the bequest of the sixteenthcentury Archbishop of Canterbury, Matthew Parker, who, seeking consolidation of the English Church in the domestically and internationally turbulent years following the breach with Rome, had gathered and studied the most ancient records of the Church in England.

10. George Biddell Airy (1801 - 1892) had recently (1828) been appointed Professor of Astronomy in Cambridge. Grundtvig's alertness to language and its scope for punning shows itself here, where he spots the opportunity afforded by the astronomer's name: 'luftig' means 'airy' - with overtones of the windbag and of one who would benefit from keeping his feet a little more on the ground, or his young wife a little more entertained of an evening.

11. Charles Heaton, in whose home Grundtvig met with hospitality, and whose wife was "one of those women who can say just what they like" [»af de Koner, der kan sige hvad de vil« - Letter to Lise, 25 June 1830]: she had asked him brazenly across the dinner-table whether he and his umbrella were quite inseparable. It was there that Grundtvig met »my neighbour at table, a young lady (I don't know whether unmarried or a widow), Mrs Bolton, who after dinner settled into conversation with me 
and is the most interesting English lady I have yet seen « [»min Sidemand ved Bordet, en ung Dame (jeg ved ikke om Jomfru eller Enke) Mrs. Bolton, som, efter Bordet, gav sig i Snak med mig, og er den interessanteste engelske Dame, jeg endnu har seet « - same Letter]. Mrs Bolton, rich, and in fact married but with a great degree of independence, insisted that Grundtvig should call on her - »for which purpose I received her address and see that she lives in the most distinguished part of the West End" [»hvortil jeg fik hendes Addresse og seer, hun boer i den allerfornemste Deel ad Vest-Enden «]. Grundtvig concludes if he is to get into contact with English men, the women will have to approve of him first "which is certainly not something I should have dreamed of, before my coming here, as a possibility « [»hvad vist nok var Noget, jeg ei før mit Komme her, skulde drømt om Mueligheden af « - same Letter]. Now Grundtvig, a year later, is insisting to a still brazen and disbelieving Mrs Heaton that he would not even recognise Mrs Bolton if he saw her.

12. It was during the three-month-long summer vacation when undergraduates, and commonly the dons, left the University.

13. Black, Young \& Young, the London publishers, had in the previous year published Grundtvig's prospectus Bibliotheca Anglo-Saxonica, in which Grundtvig outlined a subscription-based project for getting into print the whole surviving corpus of Anglo-Saxon writings, plus some other later medieval works. Grundtvig was to experience a bitter disappointment when he visited Black upon his return to London: he discovered that a rival proposal for the publication of the Anglo-Saxon manuscripts had been set up under the auspices of the Society of Antiquaries and published by Black, and that several of his own former supporters had signed up to the rival project - which was shortly to prove the successful contender.

14. Johan, Svenn (or Svend) and Meta were Grundtvig's children, who were educated at home according to Grundtvig's own principles, and whose progress he followed throughout the correspondence between him and Lise during the England-visits. Jane, often referred to as Tante Jane [Aunt Jane], was Jane Mathia Blicher, sister of Lise, a woman held in much esteem by friends of the family, who lived for many years as a member of the Grundtvig household until Lise's death in 1851. 